\title{
き裂を有する溶接材の変形挙動に及ぼす 機械的応力緩和の影響*
}

\author{
小田 勇**, 坂本 英俊 ${ }^{* * *}$, 山本 光治 ${ }^{* * *}$ \\ Effect of Mechanical Stress-Relieving on Deformation Fields \\ near a Crack in Weldment*
}

by Isamu Oda**, Hidetoshi Sakamoto*** and Mitsuharu Yamamoto***

Considerable papers which experimentally examined the effect of residual stress on the brittle fracture strength of weldment have been published. The effect of stress-relieving on the brittle fracture strength has been experimentally examined too. In those papers, the residual stress distributions were measured by the stress-relaxation method, assumed as a simple curve and represented by a simple function. There have been, however, few analytical works concerned with stress and strain near a crack in the residual weld stress field.

In the present study, an as-welded plate and a welded plate stress-relieved mechanically are dealt with. Each of them has a through-thickness center crack perpendicular to the welding bead. The crack initiates after welding or after stress-relieving. The residual stresses due to welding and those after stress-relieving by the uniform pre-straining are measured by means of the ultrasonic technique, because, from a practical point of view, the residual stress should be measured nondestructively. A uniform tensile load perpendicular to the crack is applied to the plate. Stress, strain, plastic zone near a crack and crack opening displacement are examined by elasto-plastic finite element analysis as well as experiment. Considering the residual stresses distributed after pre-cracking, the deformation near the tip of a crack in a plane stress field are analyzed. The effect of residual stresses and that of stress-relieving on the deformation near a crack are revealed. The tensile residual stress around a crack tip contributes to the increase of stress, strain, plastic zone size near the crack and crack opening displacement. The stress-relieving contributes to the increase of fracture strength of welded plate.

Key Words : Residual Stress, Weldment, Mechanical Stress-Relieving, Acoustoelasticity, Finite Element Method, Deformation, Plastic Zone, Crack Opening Displacement

\section{1. 緒 言}

溶接残留応力が継手の脆性破壊強度に及沽す影響につ いては，既に実験的に"1) あるいは破壊力学的に22検討が なされている。応力搪大係数に関する溶接残留応力の影 響についても報告されている゙.またいくつかの方法に よって溶接残留応力を緩和できることも知られてい る4).しかしながら, 溶接材の破壞に密接な関連をもつ, き裂近傍の変形挙動に及ぼ主残留応力の影響を詳細に解 析した研究はまだ少ないようである。ささらにここれまで の研究では溶接残留応力の分布として, 別の試験片に対 する弛緩法によって測定されたもの䭪比較的簡単な形 状に仮定したもの皇等が用いられている。しかしなが ら, 残留応力の大きさと分布は, 非破壊的に実測するこ とができれば，その結果を用いることが害用上最良であ る. 著者らは, 溶接残留応力の絶対值測定および機械的 な残留応力緩和の評価に対して，非破壊的応力测定法で ある音弹性法を適用し，その有効性を検討しだ). また， 音弾性法による残留応力の測定結果を組み入れた FEM 解析によって溶接材の変形挙動を明らかにした7). 本研 究では，機械的な方法で残留応力緩和を施した溶接材に

\footnotetext{
*原稿受付 平成 4 年 1 月 23 日 平成 2 年度秋季全国大会で発表

**正 員 熊本大学工学部 Member, Kumamoto University

*** 熊本大学工学部 Kumamoto University
}

ついて, 残留応力を音弾性法で測定し，その結果を組み 入れた FEM 弾塑性解析および実験を行い, き裂近傍の 変形挙動に及ほす機械的残留応力䋸和の影響を検討す る.

\section{2. 実験}

板厚 $25 \mathrm{~mm}$ の軟鋼平板から Fig. 1 のような試験片を 作製した. 試験片の長手方向は圧延方向に一致させた. 試験片中心線 ( $\mathrm{y}$ 軸) に図に示すようなV型清を切削加 Iし, 表裹両面から各 2 層の被覆アーク溶接ビードを置 き,その後, 溶接線方向に一様引張りを加えて除荷した. この機械的な残留応力緩和の後に, 図のような溶接線に 直角方向の板厚貫通中央き裂を人工的に導入した（これ を type SR と称する). 比較のために, 機械的な残留応力 緩和を施していない同様な溶接材に人工き裂をつけたも の（type T) および，溶接を行っていない同寸法のき裂 材 (type N) も用いて, 変形挙動に及沽す機械的残留応 力緩和の影響を検討した。き裂の両先端の長さ $3 \mathrm{~mm}$ は 直径 $0.03 \mathrm{~mm}$ のワイヤによるワイヤカット放電加工に よって設定した。実験では，これらの試験片にy方向の 一様引張りを加えたときの $\mathrm{x}, \mathrm{y}$ 両方向のひずみおよび き裂開口変位を測定した。ひずみは試験片両面の $\mathrm{x}$ 軸上 に貼付した標点距離 $2 \mathrm{~mm} の 2$ 軸ひずみダージにより 測定した，弾性範囲内では，2 万向のひずみ測定值と平 面応力での応力ーひずみ関係式から, $\mathrm{x}, \mathrm{y}$ 両方向の応力 


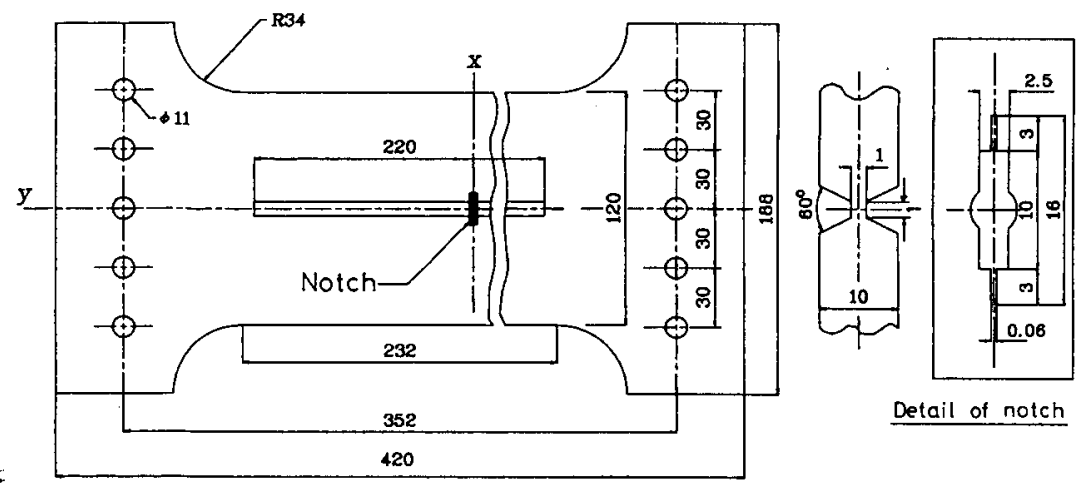

Fig. 1 Specimen used in experiment.

を得た。

\section{3. 変形挙動の解析}

解析はひずみ増分理論に基づく FEM 弾塑性計算 ${ }^{81}$ に よって行い, 平面応力と仮定した. 解析では, 実験で用 いた試験片に対応させて, Fig. 2 に示すような 3 type の モデルを用いた。材料のひずみ硬化特性は次のような Swift の式に従うものとし, 材料定数には Table $10 も$ のを用いた。

$$
\bar{\sigma}=\mathrm{c}(\alpha+\bar{\varepsilon})^{\mathrm{n}}
$$

ここで, $\bar{\sigma}(\mathrm{MPa})$ および ひずみである，なお，試験片は溶接，応力緩和のための 過ひずみ，き裂加工等の応力ーひずみ履歴を受けており， 厳密にはこれらが材料の異方性やひずみ硬化則に影響す ると考えられる。しかし，本報では降伏条件として Mises の条件を用い, 移動硬化や複合硬化は考慮していない. 材料定数は，溶接部断面の硬さ試験ちよび従来用いられ ている硬さと強度の関係" に基づいて，母材抽よ゙(溶接



Type $\mathrm{N}$

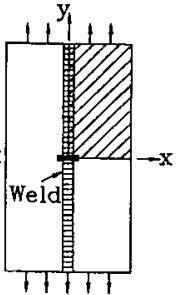

Type T



Type SR
Fig. 2 Models for FEM analyses.

Table 1 Mechanical properties of material used.

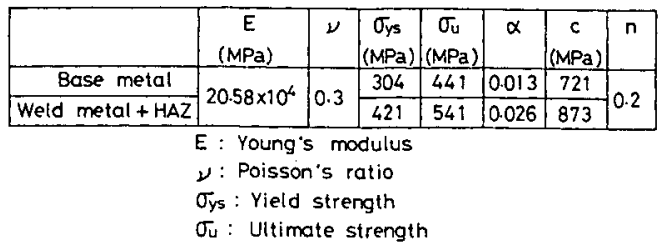

金属+HAZ)で異なる值とした．要素分割において，き 裂先端近傍は底辺 $0.05 \mathrm{~mm}$, 高さ $0.05 \mathrm{~mm}$ の二等辺三角 形とした。

type Tおよび type SR では, 残留応力（き裂導入後 の再分布応力）を計算に組み入れた。この残留応力は実

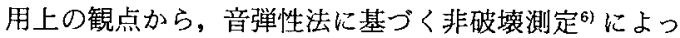
て得た。測定では, 弱い直交異方性と平面応力状態を仮 定した，供試材における音弾性に関する係数，およひ， $\mathrm{x}$ 軸上の各測定点における組織音詐異方性と無応力時の 縦波と横波の音速比を溶接前にあらかじめ測定してお き, 溶接後あるいは機械的心力緩和後に音響異方法（横 波の音速変化率）および音速比を測定した。音速は超音 波パルスを垂直法によって板厚方向に入射し，底面から の多重反射エコーを利用してパルスエコーオーバラップ 法により測定した。

Fig. 3 は超音波横波による音響異方性のみを利用して 測定した ${ }^{101}$, 縦方向残留応力 $\sigma_{\mathrm{ry}}$ と横方向残留応力 $\sigma_{\mathrm{rx}}$ の差のX軸上における分布である。この場合，横波の振 動方向は, 主応力軸が溶接線方向及びこれと直角方向に 一致するとみなして決定した。図には，type SRにおい て, 溶接のままの状態で測定した結果と，これに過ひず みによる機械的残留応力緩和を施し,さらに，き裂を導 入した後の測定結果を比較して示している。この場合， 機械的残留応力緩和のための一様引張り net 応力は母材 降伏点の0.8倍であるが,過ひずみによって残留応力がか なり緩和されていることが認められる. 奏際の変形挙動 解析に際しては, 残留応力の差ではなく絶対値が必要と なる. type Tに肪いては，上述のような超音波横波によ る音響異方性に加えて, 縦波と横波による音速の比を測 定し, それらの結果を組合わせることによっで'1), $\sigma_{\text {ry }}$ 扔 よび $\sigma_{\mathrm{rx}}$ の絶対値を得た. Fig. 4 はこのようにして求め た type Tに扔ける $\sigma_{\mathrm{ry}}, \sigma_{\mathrm{rx}}$ の絶対值の, x 軸上での分布 である、破線は溶接した後でき裂導入前における残留応 力分布, また, 実線はき裂導入後に再分布した残留応力 分布である.なお，この場合，音弾性法による残留応力 測定の後, 力のつりあいや材料の降伏点等を考虑して若 干の修正を加えた。そしてこれを最小 2 乗法によって多 項式近似して計算に取り入れた. type Tでは, Fig. 4 の 実線の残留応力分布を組み込んで変形举動解析を行っ た.ところで, type SRにおける $\sigma_{\mathrm{rx}}$ は, 板端においては 当然 0 であるが, Fig. 3 の実線における正負の力の比較 


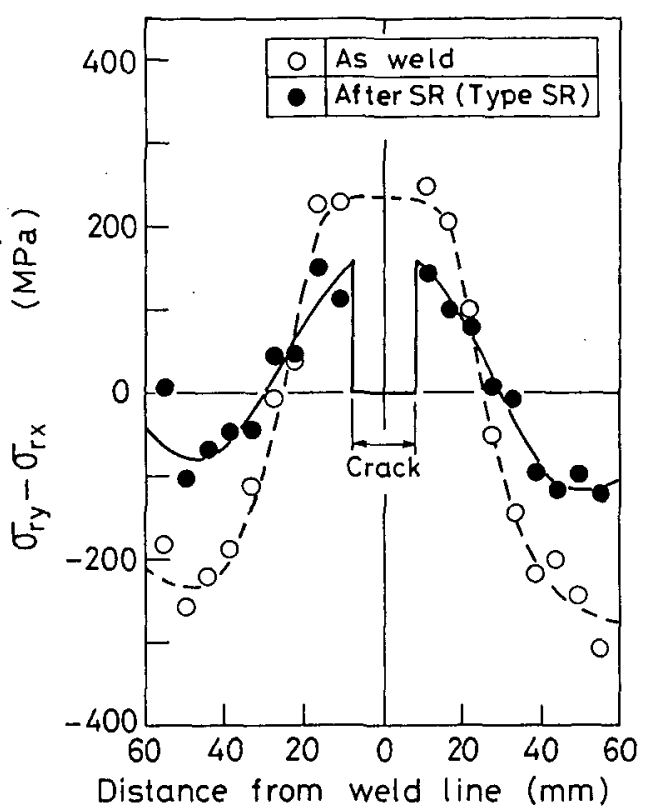

Fig. 3 Distributions of difference of residual stresses.

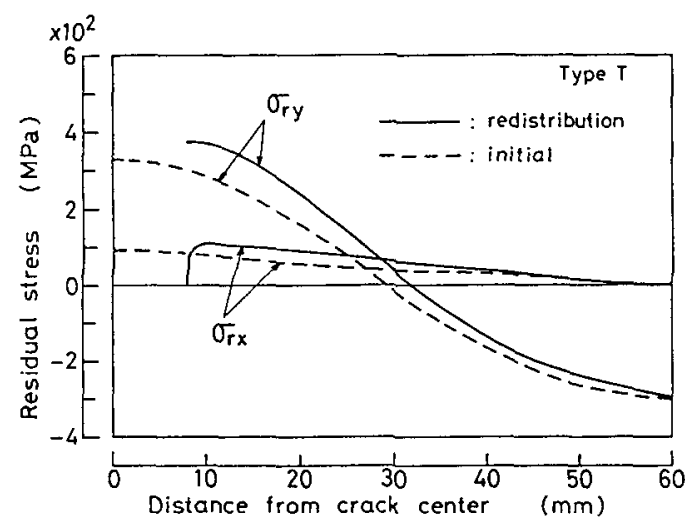

Fig. 4 Distributions of residual stress (Type T).

を行ってみると, 引張り残留応力で最も大きな值を示す と予想されるき裂先端付近でも，かなり小さな $\sigma_{\mathrm{rx}}$ 值で あると思われる。このような小さな絶刘值を本実験のよ うな方法で精度よく求めることはやや困難である゙。. そ こで本報では, type SRにおいては近似的に $\sigma_{\mathrm{rx}}$ は 0 と みなし, Fig. 3 に扔ける実線を $\sigma_{\mathrm{r} y}$ の分布と仮定して計 算に取り入れた。 なお，残留応力は， $\mathrm{x}$ 座標が一定であ つてもy座標によって異なる。この残留応力の y方向分 布は, 文献7）におけると同様に線形に変化すると仮定し た。 また，き裂面 $(-8 \mathrm{~mm} \leqq x \leqq 8 \mathrm{~mm}, y=0)$ において は当然 $\sigma_{\mathrm{ry}}=0$ であるが, 簡単化のため, $-8 \mathrm{~mm} \leqq \mathrm{x} \leqq 8$ $\mathrm{mm}$ の範囲ではy 座標にかかからず， $\sigma_{\mathrm{ry}}=0$ とした。

\section{4. 結果と考察}

Fig. 5 はy 方向に一様引張りを加えたときの, y 方向 応力 $\sigma_{y}$ のき裂延長線上における分布である。ただし，図 は解析結果で残留応力を含んだ值を示し, 応力比が 0.40 場合である。ここで, 応力比は外荷重による最小実断面 での平均応力 $\sigma_{\text {net }}$ と母材の降伏応力 $\sigma_{y s}$ との比である. 以下の図は同じ応力比 0.40 場合について示すこととす る. Fig. 5 によると,いずれの typeにおいてもき裂先端 での応力集中が明らかであるが,き裂先端付近の $\sigma_{y}$ 值は 残留応力の影響により, 大きい方から type T, type SR, type $\mathrm{N}$ の順となっている. type SRにおけるき裂先端付 近の $\sigma_{\mathrm{y}}$ は残留応力緩和の影響により, type Tのそれに 比べてかなり低下していることがわかる。また，き裂先

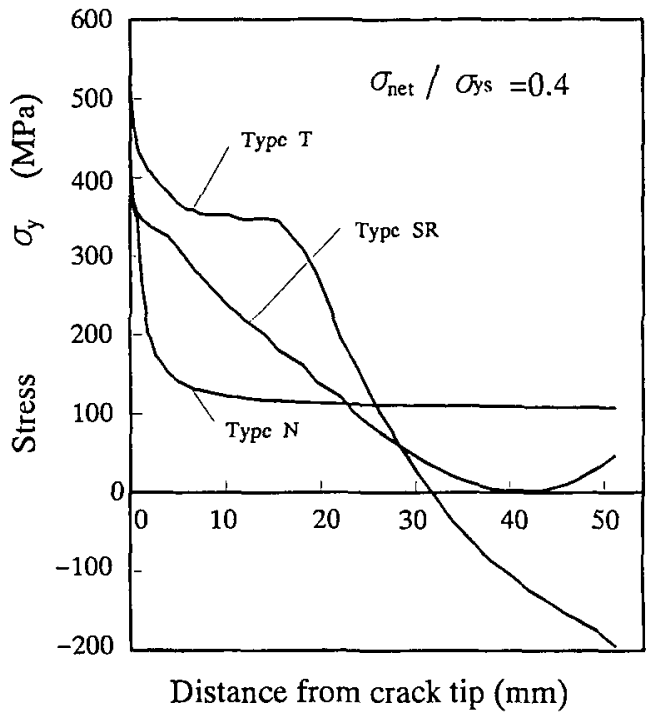

Fig. 5 Distributions of stress $\sigma_{y}$ on the prolongation of crack.

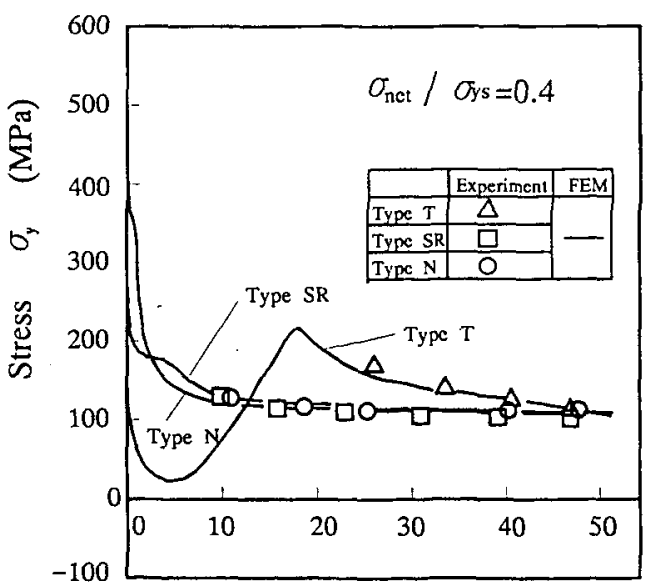

Distance from crack tip (mm)

Fig. 6 Increase of stress $\sigma_{\mathrm{y}}$ caused by external load. 
端から離れた位置での $\sigma_{y}$ も,外力を加える前の残留応力 の影響をうけた分布をなしている.これらの $\sigma_{\mathrm{y}}$ のうちか ら残留応力を除いて, 外力による $\sigma_{y}$ の増加量の, き裂延 長線上の分布を求めると Fig. 6 のようになる.type Tで は,Fig. 4 に示したようにき裂先端領域に母材の降伏応 力程度の引張応力 $\sigma_{\mathrm{ry}}$ が残留していたために, 外力の小 さな段階からすでに塑性領域が大きく搪がり，従ってそ の領域での, 外力による $\sigma_{y}$ の增加は極めて小さい. type SRにおいても，き裂先端の極く近傍では同様の理由か ら, 溶接なしの type $\mathrm{N}$ に比較して $\sigma_{y}$ の増加量は小さく なっている.しかし，き裂先端の極く近傍以外の領域で は, type $\mathrm{N}$ の場合とほほ同様の $\sigma_{\mathrm{y}}$ の増加を示す。図の 弾性領域では，2軸ひずみゲージによるひずみ測定值を 用いて計算した, 平面応力での $\sigma_{y}$ の実験値を併記してい るが, 各 typeで解析結果と実験結果はよい一致を示し ている.

Fig. 7 はy 方向の見かけのひずみ $\varepsilon_{\mathrm{y}}$ のき裂延長線上 における分布である。図は解析結果で残留ひずみを含ん



\section{Distance from crack tip (mm)}

Fig. 7 Distributions of strain $\varepsilon_{y}$ on the prolongation of crack.

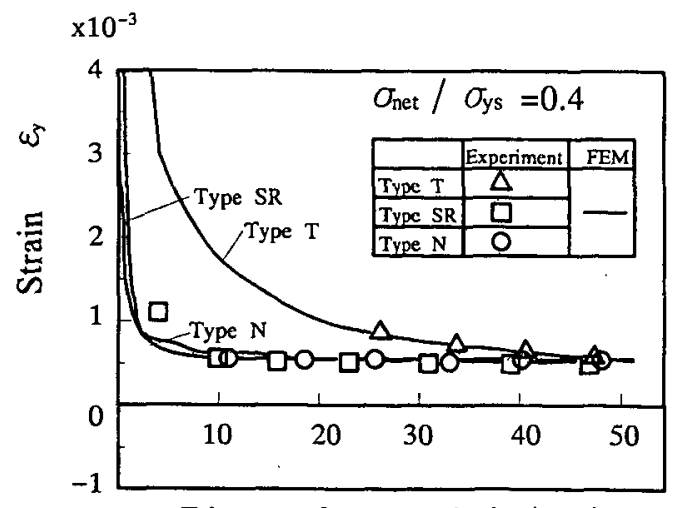

Distance from crack tip (mm)

Fig. 8 Increase of strain $\varepsilon_{y}$ caused by external load.
だ值を示す、いずれの typeでもき裂先端近傍でのひず み集中が明らかである. type Tではこのひずみ集中と引 張残留ひずみが重畳するために，き裂先端近傍では，溶 接なしの type N に比較して極めて大きな引張ひずみを 生じている. type SR では残留応力緩和により, き裂先 端付近の $\varepsilon_{y}$ は type Tより大きく低下し, 全般的には, type $T$ と type $\mathrm{N}$ の中間の分布状態を示している.これ から残留ひずみを除いて, 外力による $\varepsilon_{y}$ の增加の分布を 求めると, Fig. 8 のようになる, type Tでは, 引張残留 応力の影響で, 低い負荷段階からき裂先端付近に塑性領 域が大きく拡がるため，この付近の $\varepsilon_{y}$ 值は他の typeに 比べて極めて大きくなっている. type SRにおける塑性 領域の大きさを type Tに比較すると, 残留応力緩和の 影響により，後述のようにき裂先端の極く近傍に限定さ れて㹨くなる. 従って type SR は, その領域では, 溶接 なしの type $\mathrm{N}$ より大きな $\varepsilon_{\mathrm{y}}$ 值を生じるが, type $\mathrm{T}$ に比 べると, き裂先端付近の $\varepsilon_{\mathrm{y}}$ 值はかなり小さくなってい る。また,き裂先端から離れると, type $\mathrm{N}$ とほ沽同様の $\varepsilon_{y}$ 分布を示している。図には，解析結果と実験結果を併 記しているが，両者にはよい一致が見られる。

Fig. 9 は応力比 0.4 において, き裂先端から拡がった塑 性領域の大きさを各 typeについて示したものである。 type Tでは,き裂先端付近に残留していた大きな引張応 力のために, 外力が加わる前にすでに塑性領域が生じて いるが (図で Initial と表示している)，外力が加わると， この Initial 領域を含めた極めて大きな塑性領域を形成 する.この塑性領域の大きさは type Nのそれに比べて 極めて大きなものである。また，この塑性領域は $\mathrm{x}$ 方向 へも搪がるが，引張残留応力が存在する $\mathrm{y}$ 軸に沿う方向 への拡がりが顕著である.type SRにおける塑性領域は, type Nよりは大きな抎がりを示しているが, 残留応力䋧 和の影響をうけて, type Tに比べると著しく減少してい ることが明らかである。すなわち，同一応力比（同一負 荷段階）においてき裂先端部の塑性領域の大きさを比較 すると, 残留応力緩和材 (type SR) の塑性領域は, 溶接 のままの材 (type T) と溶接なしの材 (type N) のそれ らの中間の大きさとなっている。

き裂先端から内部へ $4 \mathrm{~mm}$ の位置における開口変位 $\mathrm{Vg}$ と一様引張り gross応力 $\sigma$ との関係を示すと Fig. 10のようになる。aはき裂の半長である。図にはクリッ プゲージで測定した結果と FEM 解析結果を併記してい



Fig. 9 Plastic zones. 


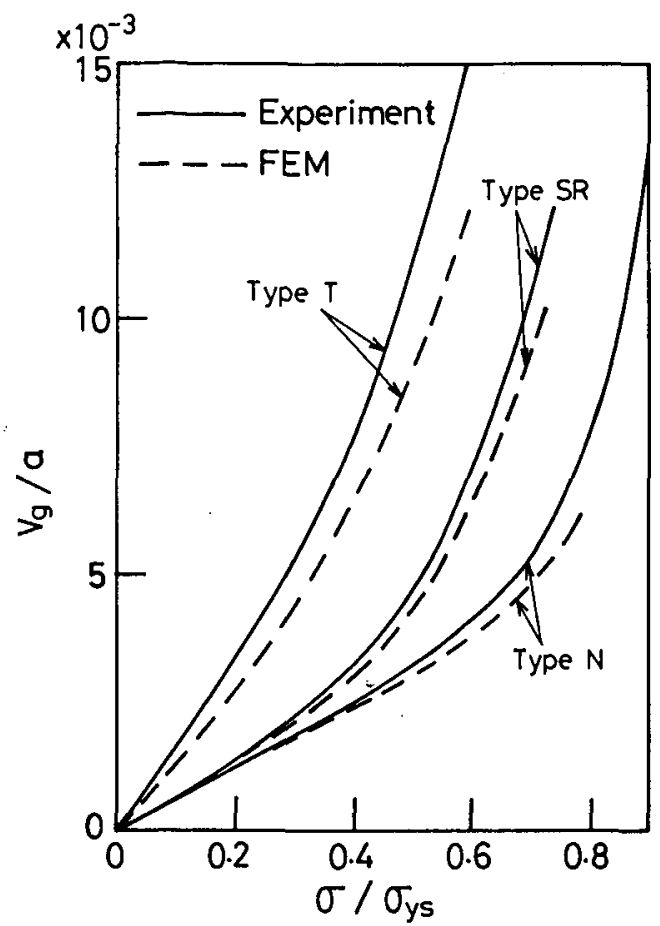

Fig. 10 Relationships between crack opening displacement and applied stress.

るが，両者に若干の差が認められる。これには，解析に おけるメッシュ分割その他の仮定など種々の影響因子が 考えられるが, 前述のように type T, type SRにおい て, $-8 \mathrm{~mm} \leqq \mathrm{x} \leqq 8 \mathrm{~mm}$ の範囲では $\mathrm{y}$ 座標にかかわらず $\sigma_{\mathrm{ry}}=0$ と仮定したことや, type SR では $\sigma_{\mathrm{rx}}=0$ とみなし たことも影響しているものと思われる.しかしながら， 実験結果と解析結果はほほ同様の傾向を示している。き 裂開口变位を同一負荷段階で比較すると, 前述のような 塑性領域の搪がり方に対応して, 大きい方から type T, type SR, type N の順となっている。 そして, 引張りの 溶接残留応力場に存在するき裂（type T) の開口変位の 著しい上昇を, type SR のような残留応力緩和によって, かなり抑制できることがわかる。このような結果から, COD 仮説に基づいた場合,もし, 各 type て破壊じん性值 にそれ程大きな差がなければ, 残留応力緩和を施すこと により，溶接材における破壊強度の低下をある程度まで 防止できること ${ }^{12\rangle}$ が説明できる.

なお，文献6)に示したように，過ひずみの程度によっ ては溶接残留応力を極めて良く緩和することができる. そのような残留応力緩和材に扔ける変形挙動は, type N の場合とおおよそ同様なものとなり得ることが予想され る.

\section{5. 結論}

突合せ溶接材掞よびこれに機械的な残留応力楥和を施 した材において, 残留応力を音弾性法によって非破壊的 に測定し，その結果を組み入れた FEM 弾塑性解析と実
験によって, 残留応力場にき裂を有する材の変形挙動を 求めた. そして, 変形挙動に及浑す残留応力緩和の影響 について検討した．得られた結果を要約すると次のよう になる。

（1）残留応力緩和材 (type SR) においては, 負荷後の 応力 $\sigma_{y}$ のき裂延長線上での分布は, 応力緩和を施してい ない溶接材 (type T) と溶接なしの部材 (type N) との 中間的なものとなる. type SRにおいては, 残留応力を 含まない, 外力による $\sigma_{y}$ の增加量は, type T の場合と 同様に，そのときのき裂先端近傍の塑性領域内では, type Nよりも小さくなる.しかし, それ以外の領域では, おおよそ type $\mathrm{N}$ と同様の $\sigma_{\mathrm{y}}$ の増加量を示す。

(2) type SRにおけるひずみ $\varepsilon_{y}$ の, き裂延長線上での 分布は，残留応力緩和の影響により，き裂先端付近では type Tの場合よりかなり減少し, 全般的な分布としては type $\mathrm{T}$ と type $\mathrm{N}$ の中間的なものとなる. type SRにお ける,残留ひずみを含まない, 外力による $\varepsilon_{y}$ の増加量は, type Tに比べて大きく滅少する. type $\mathrm{N}$ と比較した場 合，そのときのき裂先端近傍の塑性領域内では，かなり 大きな $\varepsilon_{y}$ の増加量を示すが，その他の領域ではおおよそ 同様な $\varepsilon_{y}$ 分布となる。

(3) type SRにおけるき裂先端付近の塑性領域の大き さは, 残留応力緩和の影響をうけて, type T の場合より 著しく小さくなり, type $\mathrm{T}$ と type $\mathrm{N}$ の場合の中間的な ものとなる.

(4) type SRに扔けるき裂開口変位は, 残留応力緩和 の影響により type T の場合よりかなり低下し, type T と type $\mathrm{N}$ の場合の中間的なものとなる.

(5) 非破壊的応力測定と解析とを組み合わせることに よって, 変形挙動に及ぼす残留応力緩和の効果を推定す ることができる。

\section{参 考 文 献}

1）秋田，矢田，酒井：銅構造物に発生する脆性破㙹と笺留応力，日 本造船学会論文集, 第125号 (1969)，227-235。

2）佐藤，豊田：溶接継手の脆性破罗強度に及被す残留応力と材料 の力学的特性の影響, 日本造船学会論文集, 第131号 (1972), 355 -365 .

3) H. Tada and P.C. Paris: The Stress Intensity Factor for A Crack Perpendicular to the Welding Bead, Int. J. of Fracture, 21 (1983), 279-284.

4）溶接学会編：溶接・接合便覧，丸普 (1990)，147-153,

5) H. Kihara and K. Masubuchi : Effect of Residual Stress on Brittle Fracture, Welding Journal, 38-4 (1959), 159s-168s.

6) 小田, 岩崎, 行徳 : 溶接残留応力とその機械的綑和効果の音弾性 法による非破壊評価，溶接学会論文集，9-2(1991)，299-304。

7）小田, 坂本, 雑賀、木村：き裂を有する溶接材の変形举動に及虻 す残留応力の影蠁，溶接学会論文集，8-3 (1990)，409-414。

8）山田：塑性・粘弹性，培風館（1972）.

9）吉沢編：硬さ試駼法とその応用，裳華房 (1977)，287.

10）徳岡, 岩清水: 音弾性, 機械の研究, 27-7 (1975)，860-864.

11) H. Toda, H. Fukuoka and Y. Aoki : R-value Acoustoelastic Analysis of Residual Stress in A Seam Welded Plate, Jap. J. Appl. Phys., Supplement 23-1 (1984), 86-88.

12) H. Kihara, K. Masubuchi, K. lida and H. Oba: Effect of Stress Relieving on Brittle Fracture Strength of Welded Steel Plate, IIW Document X-218-59 (1959). 